\title{
Asosiasi Dan Distribusi Spasial Permukiman Kumuh Di Kota Yogyakarta
}

\author{
Mohammad Isnaini Sadali, Fitri Noviyanti, Rifan Andika
}

Masuk: 24092019 / Diterima: 02122019 / Dipublikasi: 31122019

(c) 2019 Fakultas Hukum dan IImu Sosial UNDIKSHA dan IGI

\begin{abstract}
Yogyakarta City, as the provincial capital, city center, service center, and regional economic center, has an attraction for the population. This increases population pressure on land and is the reason why people choose marginal land for urban dwelling. Slums arise because of the inability of the community to meet the needs of the board, as well as a lack of awareness to maintaining the cleanliness and health of the living environment. This study aims to identify and map the spatial distribution of slums and their associations with significant rivers in Yogyakarta City through geospatial analysis. Slum area in Yogyakarta City is $264.90 \mathrm{Ha}$ or $8.58 \%$ of the total area of Yogyakarta City, spread in almost all districts (13 of 14 districts). Based on its proximity, the slums in the Yogyakarta City are associated with the three rivers that cross the Yogyakarta City, namely the Winongo River, the Code River, and the Gajah Wong River.
\end{abstract}

\section{Key words: Slums; Geospatial; Regional Development}

\begin{abstract}
Abstrak Kota Yogyakarta sebagai ibukota provinsi, pusat kota, pusat pelayanan, dan pusat ekonomi wilayah memiliki daya tarik bagi penduduk. Hal tersebut meningkatkan tekanan penduduk terhadap lahan dan menjadi penyebab masyarakat memilih lahan marginal untuk tempat tinggal di perkotaan. Permukiman kumuh muncul karena ketidakmampuan masyarakat memenuhi kebutuhan papan serta kurangnya kesadaran menjaga kebersihan dan kesehatan lingkungan tempat tinggal. Penelitian ini bertujuan untuk mengidentifikasi dan memetakan sebaran permukiman kumuh dan asosiasinya dengan sungai utama di Kota Yogyakarta melalui analisis geospasial. Luas kawasan permukiman kumuh di Kota Yogyakarta sebesar 264,90 Ha atau 8,58 \% dari luas Kota Yogyakarta, tersebar hampir di seluruh kecamatan (13 dari 14 kecamatan). Berdasarkan kedekatannya, permukiman kumuh di Kota Yogyakarta berasosiasi dengan ketiga sungai yang melintasi Kota Yogyakarta yaitu Sungai Winongo, Sungai Code, dan Sungai Gajah Wong.
\end{abstract}

Kata kunci : Permukiman Kumuh; Geospasial; Pembangunan Wilayah

\section{Pendahuluan}

Setiap manusia memiliki

kebutuhan primer (pokok) yaitu pangan, sandang dan papan. Ketiga kebutuhan tersebut wajib untuk dipenuhi sebagai syarat kehidupan yang baik dan layak. Kebutuhan manusia akan papan atau yang sering disebut sebagai tempat tinggal harus diperhatikan, diusahakan, dan dipenuhi oleh penduduk. Pemerintah Republik Indonesia telah menetapkan terkait permukiman dalam Undang-

Mohammad Isnaini Sadali, Fitri Noviyanti, Rifan Andika Fakultas Geografi, Universitas Gadjah Mada

m.isnaini.s@ugm.ac.id
Undang Dasar (UUD) 1945 dan pasal 28 H Amandemen UUD 1945, rumah adalah salah satu hak dasar setiap rakyat Indonesia, maka setiap warga negara berhak untuk bertempat tinggal dan mendapat lingkungan hidup yang baik dan sehat. Selain sebagai tempat tinggal, rumah juga merupakan tempat untuk meningkatkan mutu dan kualitas kehidupan dan penghidupan serta dalam pembentukan watak, karakter dan kepribadian bangsa. Hal ini didasari oleh Undang-Undang No. 4 tahun 1992 tentang Perumahan dan Permukiman, bahwa rumah adalah bangunan yang berfungsi sebagai tempat tinggal atau hunian dan sarana pembinaan keluarga. 
Sarana prasarana permukiman sebagai penunjang kehidupan sosial, ekonomi dan budaya menjadi penting dalam pemenuhan kebutuhan hidup. Adapun perkembangan penduduk yang semakin pesat mempengaruhi akan kebutuhan lahan permukiman yang tentunya juga akan terus meningkat pada suatu wilayah.

Kecenderungan perkembangan permukiman yang terjadi di Indonesia secara umum dan di Kota Yogyakarta saat ini adalah mengelompok dan banyak terdapat di wilayah perkotaan atau pusat kegiatan tertentu. Daerah pusat kegiatan merupakan pusat kehidupan sosial, ekonomi, budaya, dan politik dalam suatu kota sehingga pada kawasan ini terdapat bangunan utama untuk kegiatan sosial ekonomi. Fenomena ini disebabkan karena Kota Yogyakarta sebagai pusat kegiatan dan pelayanan mampu memberikan daya tarik bagi beberapa penduduk yang memang memiliki kepentingan dan motif tertentu dengan harapan dapat diwujudkan pada daerah tujuan.

Kawasan perumahan dengan luas dan jumlah penduduk tertentu yang dilengkapi dengan sistem sarana prasarana lingkungan melalui penataan terencana dan teratur disebut sebagai lingkungan permukiman (Undang-Undang No. 4 Tahun 1992). Akan tetapi kondisi permukiman kumuh dapat menjadi hambatan dalam mengembangkan dan menciptakan kawasan dengan kualitas lingkungan yang baik.

Provinsi Daerah Istimewa

Yogyakarta telah menetapkan kawasan permukiman kumuh yang dirumuskan ke dalam Keputusan Walikota dan Keputusan Bupati, permukiman kumuh merupakan bagian dari lingkungan yang kritis dan memerlukan penanganan serius agar tercipta lingkungan permukiman yang sehat, nyaman dan harmonis (Ritohardoyo \& Sadali, 2017; Setiadi, 2014).
Rumah tidak hanya berfungsi sebagai tempat tinggal, namun rumah juga merupakan tempat untuk meningkatkan mutu dan kualitas kehidupan dan penghidupan serta dalam pembentukan watak, karakter dan kepribadian bangsa. Hal ini didasari oleh Undang-Undang No. 4 tahun 1992 tentang Perumahan dan Permukiman, bahwa rumah adalah bangunan yang berfungsi sebagai tempat tinggal atau hunian dan sarana pembinaan keluarga. Permasalahan permukiman kumuh dan rumah tidak layak huni selalu menjadi perhatian pemerintah, karena erat kaitannya dengan kemiskinan, kesejahteraan, dan kesehatan masyarakat. Menurut Rencana Strategis Kementerian Perumahan Rakyat Tahun 2010-2014, pembangunan perumahan dan permukiman masih dihadapkan pada tiga permasalahan pokok yaitu: (1) keterbatasan penyediaan rumah, (2) peningkatan jumlah rumah tangga yang menempati rumah yang tidak layak huni dan tidak didukung oleh prasarana, sarana lingkungan dan utilitas umum yang memadai dan (3) permukiman kumuh yang semakin meluas.

Kebaruan dalam penelitian ini adalah kajian distibusi spasial kawasan permukiman kumuh dan asosiasinya terhadap sungai utama, yang terdapat di Kota Yogyakarta. Kecenderungan permukiman kumuh yang mengelompok pada lokasi tertentu dan permasalahan yang muncul dikaji dalam penelitian ini. Hasil penelitian ini dapat menjadi salah satu pertimbangan pemerintah dalam pengambilan kebijakan serta dpat juga menjadi referensi keilmuan untuk mengkaji permukiman kumuh dan pembangunan wilayah secara umum, khususnya di Kota Yogyakarta dan wilayah kota lainnya.

\section{Metode}

Penelitian ini merupakan penelitian kuantitatif, menggunakan data spasial (sekunder) sebagai data utama dan 
analisis dilakukan secara deskriptif. Data utama yang dikumpulkan adalah: data permukiman kumuh Kota Yogyakarta, data spasial Kota Yogyakarta, dan dokumen Peraturan Walikota tentang permukiman kumuh. Batasan wilayah dari penelitian ini secara administrasi dilakukan di Kota Yogyakarta dengan unit analisis berbasis kawasan dan batas administrasi wilayah kota.
Proses penelitian dimulai dengan pengumpulan data permukiman kumuh yang bersumber dari peraturan walikota, menyiapkan peta dasar, dan memasukkan informasi ke dalam data spasial. Tahap selanjutnya adalah pengolahan data spasial dan analisis hasil sebaran permukiman kumuh di Kota Yogyakarta. Secara sederhana, diagram alir tapahan penelitian dapat dilihat pada Gambar 1 .

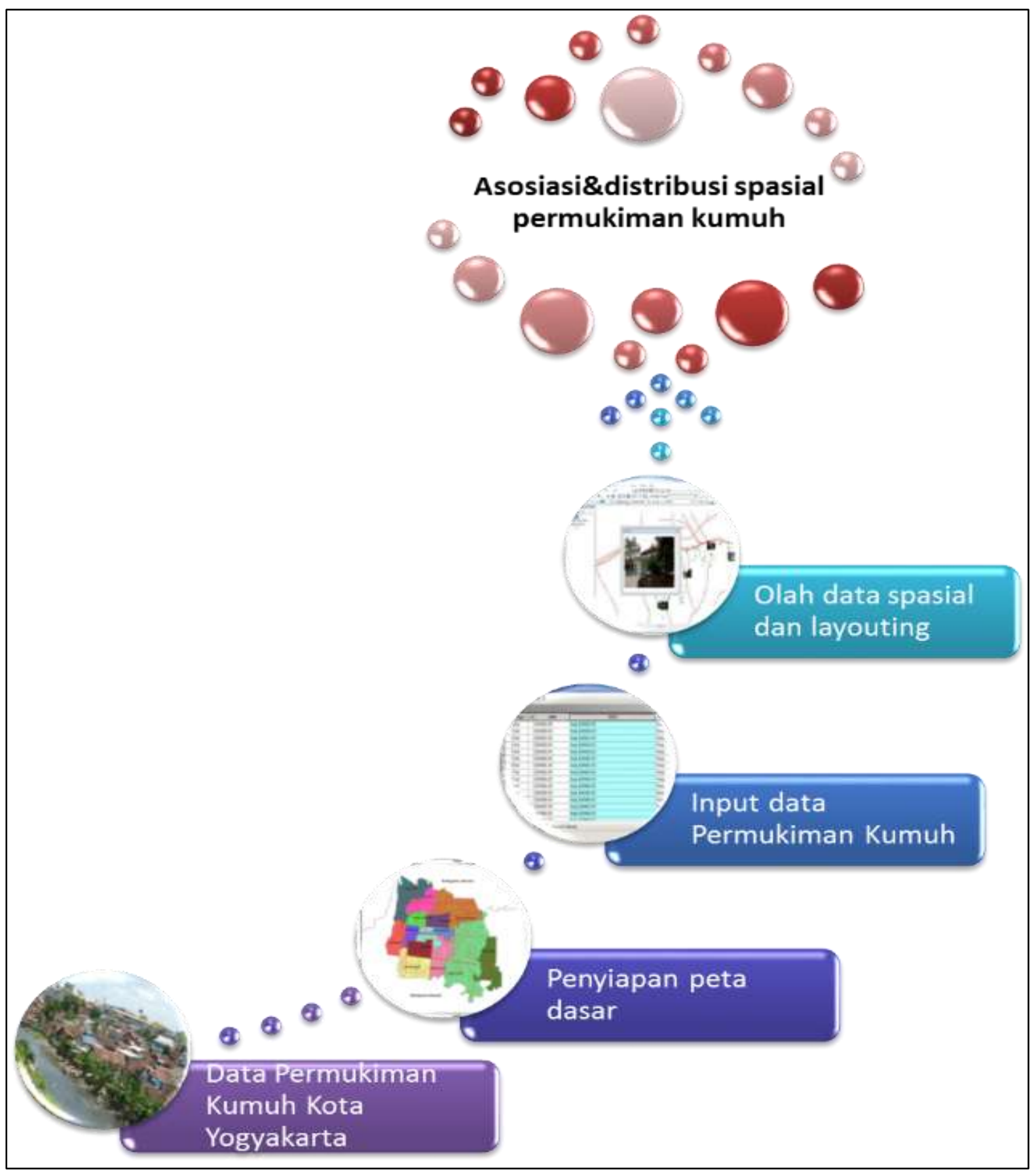

Gambar 1. Diagram Alir Tahapan Penelitian 
Teknik analisis dan pengolahan data spasial yang digunakan adalah: (1) Overlay/tumpang susun data sebaran lokasi permukiman kumuh dengan data dasar spasial Kota Yogyakarta dan wilayah administrasi (kecamatan dan kelurahan); (2) Analisis tabulasi silang (crosstab) sebaran permukiman kumuh dengan data dasar spasial Kota Yogyakarta; dan (3) Analisis klaster (cluster) untuk mengetahui ada atau tidaknya pengelompokan dari lokasi kawasan permukiman kumuh. Hasil pengolahan statistik spasial menggunakan software ArcGis akan menghasilkan dua klas, yakni spatial cluster of high value yang menunjukkan klaster pada obyekobyek yang memiliki nilai tinggi dan spatial cluster of low value yang menunjukkan klaster pada obyek-obyek yang memiliki nilai rendah.

\section{Hasil dan Pembahasan}

Menurut Rencana Strategis Kementerian Perumahan Rakyat tahun 2010-2014, permasalahan pokok yang dihadapi dalam pembangunan perumahan dan permukiman salah satunya adalah permukiman kumuh yang semakin meluas. Wilayah perkotaan menjadi salah satu tujuan penduduk yang berdampak pada tekanan kebutuhan pembangunan perumahan di wilayah perkotaan yang terus meningkat. Jumlah penduduk yang tinggal perkotaan sudah mencapai lebih dari $50 \%$ total penduduk nasional, lebih detail lagi konsentrasi pertumbuhan terjadi di kota-kota besar, metropolitan, dan sekitarnya. Lahan perkotaan yang semakin terbatas tentu saja tidak mampu menampung pertumbuhan penduduk dan pada akhirnya menimbulkan tingginya tekanan lahan oleh penduduk yang menjadi salah satu penyebab permukiman yang tidak teratur, minim fasilitas penunjang, tidak layak huni, dan kumuh.
Hal yang sama juga disampaikan bahwa salah satu indikator kawasan kumuh yang dapat menentukan kualitas kawasan pemukiman adalah infrastruktur fisik rumah dan penunjang lingkungan permukiman (Fithra, Olivia, \& Siska, 2019) serta faktor demografis, ekonomi dan pendidikan (Christiawan \& Budiarta, 2017).

Solusi terhadap penanganan permukiman kumuh yang terus mengalami peningkatan, belum dilakukan secara menyeluruh sehingga menyebabkan kondisi semakin kumuhnya permukiman dan semakin sulit diatasi. Hasil penelitian United Nation Development Programme (UNDP) mengindikasikan terjadinya perluasan permukiman kumuh mencapai $1,37 \%$ setiap tahunnya, dengan demikian luas permukiman kumuh diperkirakan meningkat menjadi $57.800 \mathrm{Ha}$ pada tahun 2009 dibandingkan dengan kondisi sebelumnya pada tahun 2004 sebesar $54.000 \mathrm{Ha}$.

Berdasarkan Surat Keputusan Walikota Yogyakarta Nomor 393 Tahun 2014 tentang Permukiman Kumuh, luas kawasan permukiman kumuh di Kota Yogyakarta pada tahun 2014 sebesar 278,7 Hektar atau 8,58 persen dari total luas wilayah Kota Yogyakarta. Sedangkan pada tahun 2015, berdasarkan hasil inventarisasi data permukiman kumuh di Kota Yogyakarta yang telah ditetapkan melalui Peraturan Walikota Yogyakarta Nomor 216 tahun 2016, maka luas permukiman kumuh di Kota Yogyakarta sebesar 264,90 Hektar atau 8,58 persen dari luas total keseluruhan Kota Yogyakarta. Terjadi pengurangan luas kawasan permukiman kumuh sekitar 5 persen dari tahun 2014. Distribusi permukiman kumuh di Kota Yogyakarta secara rinci akan dibahas pada sub bab di bawah ini dan dipetakan seperti terlihat pada Gambar 2. 


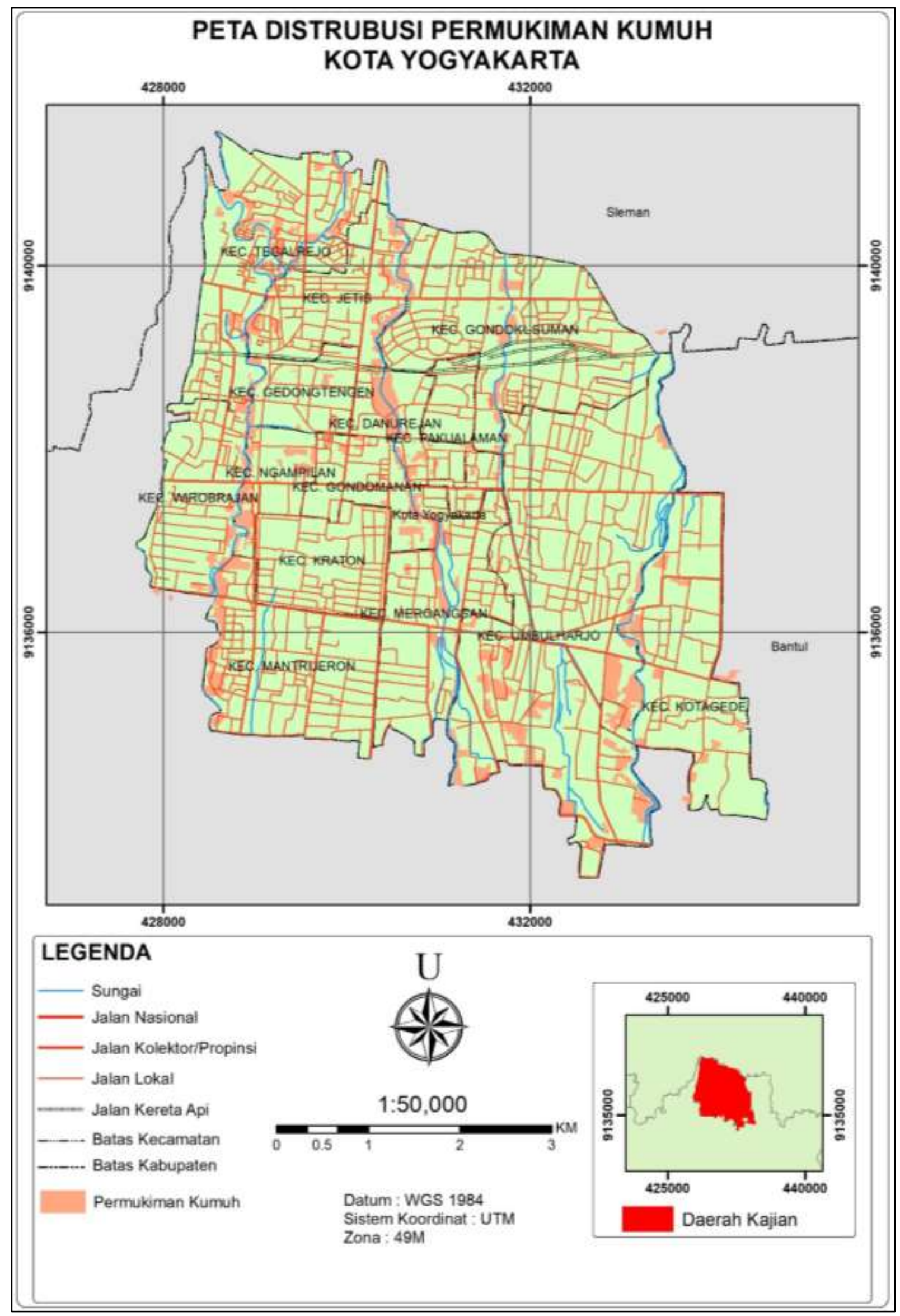

Gambar 2. Distribusi Permukiman Kumuh di Kota Yogyakarta 


\section{Distribusi Spasial Permukiman Kumuh di Kota Yogyakarta}

Berdasarkan Keputusan Walikota Yogyakarta Nomor 216 Tahun 2016 tentang Penetapan Lokasi Kawasan Kumuh di Kota Yogyakarta, terdapat 13 Kecamatan di Kota Yogyakarta yang memiliki kawasan kumuh. Ketiga belas kawasan kumuh tersebut berada di Kecamatan Mantrijeron, Mergangsan, Umbulharjo, Kotagede, Gondokusuman,
Danurejan, Pakualaman, Gondomanan, Ngampilan, Wirobrajan, Gedongtenen, Jetis dan Tegalrejo. Sedangkan kecamatan di Kota Yogyakarta yang tidak memiliki kawasan permkiman kumuh hanya berjumlah satu kecamatan yakni Kecamatan Kraton. Kawasan permukiman kumuh yang tersebar pada 13 kecamatan tersebut memiliki variasi jumlah dan sebaran di setiap kelurahan dan Rukun Warga seperti terlihat pada Tabel 1.

Tabel 1. Sebaran Kawasan Permukiman Kumuh di Kota Yogyakarta

\begin{tabular}{|c|c|c|c|c|}
\hline No. & Kecamatan & Kelurahan & Lokasi & Luas (Ha) \\
\hline \multirow[t]{2}{*}{1} & Mantrijeron & Gedong Kiwo & $\begin{array}{l}\text { RW } 1,2,6,8,9,11,12,14,15,17, \\
18\end{array}$ & 20,68 \\
\hline & & Brontokusuman & RW 16, 17, 18, 19, 20, 21, 22 & \\
\hline \multirow[t]{4}{*}{2} & Mergangsan & Keparakan & RW 2, 7, 8, 9, 10, 13 & 16,32 \\
\hline & & Wirogunan & $\mathrm{RW} 1,2,3,4,7,22$ & \\
\hline & & Giwangan & RW $1,6,8,9,12,13$ & \\
\hline & & Sorosutan & $\begin{array}{l}\text { RW } 1,2,3,4,5,6,7,8,9,10,11 \text {, } \\
12,13,14,15,16,17\end{array}$ & \\
\hline \multirow[t]{5}{*}{3} & Umbulharjo & Pandeyan & RW $8,9,10,11,13$ & 75,20 \\
\hline & & Warungboto & RW 7, 8, 9 & \\
\hline & & Semaki & RW 10 & \\
\hline & & Muja-Muju & RW 5, 6, 8, 9 & \\
\hline & & Rejowinangun & RW 7, 8, 9 & \\
\hline \multirow[t]{3}{*}{4} & Kotagede & Purbayan & RW $1,4,5,7,9,10$ & 19,64 \\
\hline & & Prenggan & RW $1,3,11,13$ & \\
\hline & & Baciro & RW 1, 3, 4, 5, 6, 7, 20 & \\
\hline \multirow[t]{2}{*}{5} & Gondokusuman & Klitren & RW 1, 3, 4, 6, 7, 8 & 19,16 \\
\hline & & Terban & $\mathrm{RW} 1,4,5,6,10,11$ & \\
\hline & & Suryatmajan & RW $1,2,3,4,7,8,9,10,11,13$ & \\
\hline \multirow[t]{2}{*}{6} & Danurejan & & 14,15 & 7,12 \\
\hline & & Tegalpanggung & RW 1, 2, 3, 13, 14 & \\
\hline \multirow[t]{2}{*}{7} & Pakualaman & $\begin{array}{l}\text { Purwokinanthi } \\
\text { Gunungketur }\end{array}$ & $\begin{array}{l}\text { RW } 1,2,4,5,7,9 \\
\text { RW } 1,3,6,7\end{array}$ & 7,51 \\
\hline & & Prawirodirjan & $\mathrm{RW} 1,2,3,5,6,8,10,11,12,14$ & \\
\hline \multirow[t]{2}{*}{8} & Gondomanan & & $15,16,17,18$ & 12,91 \\
\hline & & Ngupasan & $\mathrm{RW} 1,2,4,5,6,7,8,9$ & \\
\hline \multirow{3}{*}{9} & Naambilan & Notoprajan & $\mathrm{RW} 1,2,3,4$ & 1851 \\
\hline & & Ngampilan & $\mathrm{RW} 1,2,9,11,12$ & 18,51 \\
\hline & & Patangpuluhan & RW 5, 6, 7, 10 & \\
\hline \multirow[t]{2}{*}{10} & Wirobrajan & Wirobrajan & RW $6,7,9$ & 10,17 \\
\hline & & Pakuncen & $\mathrm{RW} 8,10,11$ & \\
\hline \multirow[t]{2}{*}{11} & Gedong Tengen & $\begin{array}{l}\text { Pringgokusuman } \\
\text { Sosromenduran }\end{array}$ & $\begin{array}{l}\operatorname{RW} 1,2,3,4,5,6,8,17,22,25 \\
\operatorname{RW} 3,10,11\end{array}$ & 6,93 \\
\hline & & Bumijo & RW $1,3,9,10,11,12,13$ & \\
\hline \multirow[t]{3}{*}{12} & Jetis & Gowongan & $\mathrm{RW} 7,8,9,10,11,12,13$ & 20,60 \\
\hline & & Cokrodiningratan & RW 5, 6, 7, 8, 9, 10, 11 & \\
\hline & & Tegalrejo & RW 1, 2, 3, 10, 11, 12 & \\
\hline \multirow{3}{*}{13} & Teqalreio & Bener & $\mathrm{RW} 1,3,4,5$ & \\
\hline & I egalrejo & Kricak & $\mathrm{RW} 1,2,3,7,8,9,10,11,12,13$ & 35,18 \\
\hline & & Karangwaru & $\begin{array}{l}\text { RW 1, 2, 3, 4, 5, 6, 11, } 14 \\
\text { TOTAL }\end{array}$ & 264.90 \\
\hline
\end{tabular}

Sumber: Peraturan Walikota Yogyakarta Nomor 216, 2016 
Lokasi kawasan permkiman kumuh di Kecamatan Mantrijeron hanya terdapat di satu kelurahan yakni Kelurahan Gedongkiwo dengan luasan total 20,65 Hektar. Sebaran lokasi kawasan permkiman kumuh di Kecamatan Mantrijeron tersebut berada di RW 1, 2, 6, 8, 9, 11, 12, 14, 15, 17 dan 18. Kelurahan Gedongkiwo berada dekat dengan Kawasan Tirtodipuran yang terkenal sebagai kawasan sentra kerajinan batik dan pusat penginapan wisatawan. Sedangkan lokasi kawasan permukiman kumuh di Kecamatan Mergangsan tersebar di seluruh kelurahan, diantaranya Kelurahan Brontokusuman, Keparakan, dan Wirogunan dengan luasan total 16,32 Hektar. Terdapat tujuh Rukun Warga di Kelurahan Brontokusuman yang tergolong dalam lokasi kawasan permukiman kumuh, yaitu RW 16, 17, 18, 19, 20, 21, dan 22. Kemudian lokasi kawasan permukiman kumuh di Kelurahan Keparakan terdapat di RW 2, 7, 8, 9, 10, dan 13. Lokasi kawasan permukiman kumuh terakhir berada di Kelurahan Wirogunan dengan sebarannya berada di RW 1, 2, 3, 4, 7, dan 22. Permukiman kumuh di Kelurahan Brontokusuman, Wirogunan, dan Keparakan berasosiasi dengan Sungai Code dan kawasan perhotelan di Kecamatan Mergangsan.

Di Kecamatan Umbulharjo terdapat enam kelurahan yang di dalamnya ada kawasan permukiman kumuh, diantaranya Kelurahan Giwangan, Sorosutan, Pandeyan, Warungboto, Semaki, dan Muja-Muju dengan luasan total 75,20 Hektar. Satu-satunya kelurahan di Kecamatan Umbulharjo yang tidak memiliki kawasan permukiman kumuh hanya Kelurahan Tahunan. Kelurahan yang memiliki kawasan permukiman kumuh paling banyak di Kecamatan Umbulharjo adalah Kelurahan Sorosutan dengan jumlah $17 \mathrm{RW}$, mulai dari RW 1 hingga RW 17 terdapat permukiman kumuh. Kawasan permukiman kumuh di
Kelurahan Sorosutan merupakan kawasan perkotaan dekat dengan Sungai Manunggal dan Sungai Code. Lokasi kawasan permukiman kumuh di Kecamatan Umbulharjo lainnya berada di Kelurahan Giwangan yang tersebar di enam RW yakni RW 1, 6, 8, 9, 12, dan 13. Selanjutnya adalah lokasi kawasan permukiman kumuh di Kelurahan Pandeyan tersebar pada lima RW yaitu RW 8, 9, 10, 11, dan 13. Kelurahan MujaMuju memiliki empat RW yang tergolong ke dalam kawasan permukiman kumuh diantaranya RW 5, 6, 8, dan 9. Kelurahan Warungboto hanya terdapat tiga lokasi RW yang memiliki kawasan permukiman kumuh yaitu RW 7, 8, dan 9. Kelurahan Giwangan, Pandeyan, dan Muja-Muju adalah kawasan yang berada di dataran rendah dan berasosiasi dengan Sungai Gajah Wong. Sedangkan lokasi kawasan kumuh di Kelurahan Semaki hanya terdiri dari RW 10 serta berada di sekitar Sungai Manunggal.

Kecamatan selanjutnya yang memiliki lokasi kawasan permukiman kumuh di Kota Yogyakarta adalah Kecamatan Kotagede. Lokasi kawasan permukiman kumuh di Kecamatan Kotagede tersebar di tiga kelurahan yakni Kelurahan Rejowinangun, Purbayan, dan Prenggan dengan luasan total 19,64 Hektar. Pada Kelurahan Rejowinangun terdapat sejumlah tiga RW yang teridentifikasi sebagai kawasan permukiman kumuh yakni RW 7, 8, dan 9. Kelurahan ini dekat dengan objek wisata Kebun Binatang Gembiraloka. Sedangkan lokasi kawasan permukiman kumuh pada Kelurahan Purbayan tersebar pada enam RW yakni RW 1, 4, 5, 7, 9, dan 10 . Kelurahan terakhir yang memiliki permukiman kumuh di Kecamatan Kotagede adalah Kelurahan Prenggan dengan empat RW diantaranya RW 1, 3, 11, dan 13. Keseluruhan kelurahan yang memiliki kawasan permukiman kumuh di Kecamatan Kotagede berasosiasi dengan 
keberadaan Sungai Gajah Wong dan termasuk kawasan permukiman kumuh di dataran rendah.

Kawasan permukiman kumuh di Kecamatan Gondokusuman tersebar di tiga kelurahan, yaitu Kelurahan Baciro, Klitren, dan Terban dengan luas 19,16 Hektar. Pada Kelurahan Baciro, lokasi kawasan permukiman kumuh tersebar di tujuh RW yakni RW 1, 3, 4, 5, 6, 7, dan 20. Kelurahan Baciro umumnya merupakan daerah dataran dengan ketinggian 200 MDPL. Kelurahan Baciro dilalui 2 (dua) sungai yaitu Sungai Gajah Wong dan sungai Manunggal. Selanjutnya kawasan permukiman kumuh juga terdapat di Kelurahan Klitren yang tersebar pada enam RW diantaranya RW 1, 3, 4, 6, 7, dan 8. Sedangkan pada Kelurahan Terban lokasi kawasan permukiman kumuh terletak di RW 1, 4, 5, 6, 10, dan 11. Kawasan permukiman kumuh di Kelurahan Terban berasosiasi dengan Sungai Belik dan Sungai Code serta dekat dengan kawasan perguruan tinggi yakni Universitas Gadjah Mada.

Kecamatan Danurejan juga teridentifikasi memiliki kawasan permukiman kumuh yang tersebar pada dua kelurahan yakni Kelurahan Suryatmajan dan Tegelpanggung. Luasan total kawasan permukiman kumuh di Kacamatan Danurejan adalah 7,12 Hektar. Pada Kelurahan Suryatmajan, lokasi kawasan permukiman kumuh tersebar pada 12 RW yakni RW 1, 2, 3, 4, 7, 8, 9, 10, 11, 13, 14, dan 15. Kelurahan Suryatmajan merupakan kawasan pusat pelayanan dan perdagangan Kota Yogyakarta yakni di sekitar Jalan Malioboro, sehingga permukiman yang dihuni oleh masyarakat berada di pinggiran pusat pelayanan. Selain itu, permukiman kumuh di Kelurahan Suryatmajan berasosisasi dengan Sungai Code. Sedangkan kawasan permukiman kumuh di Kelurahan Tegelpanggung tersebar di RW 1, 2, 3, 13, dan 14.
Kelurahan Tegelpanggung juga berasosiasi dengan Sungai Code dan lokasinya dekat dengan Stasiun Kereta Api Lempuyangan.

Kawasan permukiman kumuh di Kecamatan Pakualaman terdapat di dua kelurahan yakni Kelurahan Purwokinanthi dan Gunungketur. Pada Kelurahan Purwokinanthi, lokasi kawasan permukiman kumuh tersebar di RW 1, 2, 3, 13, dan 14. Sedangkan pada Kelurahan Gunungkatur kawasan permukiman kumuh tersebar di RW 1, 3, 6, dan 7. Kelurahan Purwokinanthi dan Gunungkathur merupakan kawasan perkotaan yang dekat dengan kawasan Malioboro dan Keraton Ngayogyakarta Hadiningrat. Selain itu, kawasan kawasan permukiman kumuh kumuh di kedua kelurahan tersebut berada dekat dengan Sungai Code.

Seluruh kelurahan yang ada di Kecamatan Gondomanan teridentifikasi terdapat kawasan permukiman kumuh dengan luasan total 12,91 Hektar. Kelurahan tersebut adalah Prawirodirjan dan Ngupasan. Lokasi kawasan permukiman kumuh pada Kelurahan Prawirodirjan tersebar di 14 RW yakni RW 1, 2, 3, 5, 6, 8, 10, 11, 12, 14, 15, 17, dan 18. Sedangkan lokasi kawasan permukiman kumuh di Kelurahan Ngupasan terletak pada RW 1, 2, 4, 5, 6, 7, 8, dan 9. Seluruh kelurahan yang memiliki kawasan permukiman kumuh di Kecamatan Gondomanan berada dekat kawasan perdagangan dan kawasan wisata seperti Pasar Beringharjo, Museum Benteng Vredeburg, dan Alun-Alun Utara Yogyakarta. Keberadaan permukiman kumuh pada kedua kelurahan tersebut berasosiasi dengan Sungai Code.

Lokasi kawasan permukiman kumuh di Kecamatan Ngampilan tersebar di dua kelurahan yakni Kelurahan Ngampilan dan Notoprajan. Pada kedua kelurahan tersebut terdapat kawasan permukiman kumuh dengan luasan total 
13,51 Hektar. Sejumlah lima RW di Kelurahan Ngampilan teridentifikasi adanya kawasan permukiman kumuh, diantaranya adalah RW 1, 2, 9, 11, dan 12. Sedangkan Kelurahan Notoprajan memiliki empat RW yang di dalamnya terdapat kawasan permukiman kumuh yaitu RW 1 hingga RW 4. Kelurahan Ngampilan dan Notoprajan berada dekat dengan pusat perkotaan dan juga dekat dengan Sungai Winongo.

Seluruh kelurahan di Kecamatan Wirobrajan juga teridentifikasi adanya kawasan permukiman kumuh, yang sebarannya berada di Kelurahan Patangpuluhan, Wirobrajan, dan Pakuncen. Luas total kawasan permukiman kumuh di Kecamatan Wirobrajan adalah 10,17 Hektar. Pada Kelurahan Patangpuluhan terdapat empat RW yang di dalamnya tergolong ada kawasan permukiman kumuh yakni RW 5, 6, 7, dan 10. Kelurahan Wirobrajan dan Pakuncen masing-masing memiliki kawasan permukiman kumuh di tiga RW yang yang tersebar di RW 6, 7, dan 9 pada Kelurahan Wirobrajan, serta RW 8, 10, dan 11 pada Kelurahan Pakuncen. Kawasan permukiman kumuh di Kecamatan Wirobrajan merupakan kawasan yang disebelah baratnya berbatasan dengan Sungai Winongo.

Kecamatan yang teridentifikasi memiliki kawasan permukiman kumuh selanjutnya adalah Kecamatan Gedongtengen yang tersebar di Kelurahan Pringgokusuman dan Sosromeduran dengan total luas sebesar 6,93 Hektar. Kelurahan Pringgokusuman memiliki 10 RW yang di dalamnya termasuk dalam kawasan permukiman kumuh yakni RW 1 , 2, 3, 4, 5, 6, 8, 17, 22, dan 25. Sedangkan lokasi kawasan permukiman kumuh yang ada di Kelurahan Sosromeduran tersebar pada RW 3, 10, dan 11. Kecamatan Gedongtengen dekat dengan kawasan pariwisata Malioboro sehingga dipenuhi dengan fasilitas perhotelan bagi wisatawan. Selain itu, permukiman kawasan kumuh yang berada di Kelurahan Pringgokusuman dan Sosromeduran berada dekat dengan Sungai Winongo.

Lokasi kawasan permukiman kumuh di Kecamatan Jetis menyebar di seluruh kelurahannya yaitu Kelurahan Bumijo, Gowongan, dan Cokrodiningratan. Luas seluruh kawasan permukiman kumuh di Kecamatan Jetis adalah 20,60 Hektar. Pada Kelurahan Bumijo, kawasan permukiman kumuh berada di tujuh RW yaitu RW 1, 3, 9, 10, 12, dan 13. Sedangkan jumlah kawasan permukiman kumuh di Kelurahan Gowongan dan Cokrodiningratan tersebar di tujuh RW yaitu RW 7, 8, 9, 10, 11, 12, dan 13 untuk Kelurahan Gowongan, serta RW 5, 6, 7, 8, 9, 10 dan 11 untuk Kelurahan Cokrodiningratan. Kelurahan Bumijo, Gowongan, dan Cokrodiningratan berada di kawasan yang berbatasan dengan Sungai Winongo di sebelah barat dan Sungai Code di sebelah timur.

Kecamatan terakhir di Kota Yogyakarta yang memiliki kawasan permukiman kumuh adalah Kecamatan Tegalrejo dengan luas 35,16 Hektar. Seluruh kelurahan yang ada di Kecamatan Tegalrejo teridentifikasi memiliki kawasan permukiman kumuh. Kelurahan tersebut adalah kelurahan Bener, Karangwaru, Kricak, dan Tegalrejo. Kelurahan Bener memiliki empat RW yang termasuk dalam kawasan permukiman kumuh yaitu RW 1, 3, 4, dan 5. Kemudian kawasan permukiman kumuh di Kelurahan Karangwaru tersebar di delapan RW diantaranya adalah RW 1, 2, 3, 4, 5, 6, 11, dan 14. Kelurahan Kricak merupakan kelurahan dengan jumlah RW tertinggi yang teridentifikasi memiliki kawasan permukiman kumuh di Kecamatan Tegalrejo yaitu sejumlah $13 \mathrm{RW}$ dimulai dari RW 1 hingga RW 13. Kelurahan terakhir adalah Kelurahan Tegalrejo dengan enam RW yang di dalamnya terdapat kawasan permukiman kumuh, 
yaitu RW 1, 2, 3, 10, 11, dan 12. Kawasan permukiman kumuh di kecamatan ini dilalui oleh 2 sungai, yaitu Sungai Winongo dan Sungai Code, di mana sebagian wilayahnya merupakan daerah pemukiman, perkantoran, pertokoan, industri kecil (khususnya industri rumah tangga), dan masih ada sebagian kecil wilayahnya berupa persawahan.

Secara keseluruhan, kecamatan dengan kawasan permukiman kumuh terluas di Kota Yogyakarta adalah Kecamatan Umbulharjo, yaitu seluas 75,20 Hektar. Luas kawasan permukiman kumuh di Kecamatan Umbulharjo sama dengan 28,39 persen dari total luas keseluruhan kawasan permukiman kumuh di Kota Yogyakarta (yaitu 264,90 Hektar). Besarnya kawasan permukiman kumuh di Kecamatan Umbulharjo identik dengan pengelompokan rumah tidak layak huni (RTLH) yang membentuk beberapa kluster (Ritohardoyo \& Sadali, 2017). Selain pengelompokan rumah tidak layak huni, fakor yang diduga menyebabkan kekumuhan adalah faktor padatnya penduduk pada lingkungan permukiman, rendahnya pendapatan masyarakat, kurangnya kepedulian masyarakat, kepadatan bangunan yang tinggi, dan kondisi prasarana yang buruk (Sulestianson \& Indrajati, 2016). Sedangkan kecamatan dengan luasan kawasan permukiman kumuh paling rendah adalah Kecamatan Gedongtenen dengan luas 6,93 Hektar.

\section{Implikasi Asosiasi Permukiman Kumuh dengan Sungai}

Secara spasial, kawasan permukiman kumuh di Kota Yogyakarta berasosiasi dengan keberadaan sungai utama yang melewati Kota Yogyakarta. Terdapat tiga sungai yang membelah Kota Yogyakarta menjadi empat bagian, yakni: (1) di sebelah barat Kota Yogyakarta dibelah Sungai Winongo, (20 di tengah Kota Yogyakarta dibelah Sungai Code, dan (3) di sebelah timur Kota Yogyakarta dibelah Sungai Gajah Wong. Sebagian besar permukiman kumuh di Kota Yogyakarta merupakan permukiman di bantaran sungai. Menurut tipologi kawasan permukiman kumuh yang dikeluarkan oleh Direktorat Jenderal Cipta Karya Kementerian Pekerjaan Umum (2014), kawasan permukiman kumuh yang ada di Kota Yogyakarta termasuk dalam kawasan permukiman kumuh di tepi air, hal ini ditunjukkan dengan sebaran permukiman kumuh yang mayoritas berada di sekitar sungai atau bantaran sungai (kawasan permukiman kumuh pinggiran sungai (KPKPS).

Sulitnya mendapatkan lahan permukiman dan desakan faktor ekonomi menjadi salah satu alasan masyarakat memilih tinggal di permukiman kumuh. Beberapa alasan mengapa orang memilih untuk tetap tinggal di kawasan kumuh adalah terbatasnya ruang dan harga tanah yang tinggi. Selain itu, penghuni juga telah tinggal di daerah itu secara turun temurun dan telah mengalami berbagai kondisi perumahan di bawah standar, padat serta tidak sehat. (Rachmawati, Prakoso, Sadali, \& Yusuf, 2018; Uddin, 2018). Hasil penelitian di beberapa kota menunjukkan bahwa beberapa migran juga berperan sebagai penghuni permukiman kumuh (Beguy, Bocquier, \& Zulu, 2010). Urbanisasi yang tidak direncanakan dan praktek pembangunan rumah di bawah standar atau di bawah mutu/kualitas dapat menimbulkan risiko besar jika terjadi bencana alam, lebih serius lagi terjadi degradasi lahan, khususnya lahan pertanian dan transformasi lingkungan (Ahmed, 2014; Bytyqi, 2018).

Perhatian utama yang perlu secara terus menerus diberikan pada penghuni kawasan permukiman kumuh adalah kurangnya kesadaran warga terhadap lingkungannya sendiri, sehingga kerap kali banyak menimbulkan permasalahan lain. Permasalahan kerentanan akan bahaya 
banjir, baik banjir genangan, banjir luapan sungai, maupun banjir lahar (lahar sebagai dampak erupsi Gunungapi Merapi) juga sering dialami penghuni permukiman kumuh di Kota Yogyakarta yang dekat dengan bantaran sungai. Salah satu permasalahan utama dalam kawasan permukiman kumuh yang menjadi salah satu pertimbangan prioritas penanganan adalah meningkatkan kualitas hunian.

$$
\text { Fakta-fakta di lapangan }
$$

menunjukkan bahwa ada beberapa masalah terkait dengan kondisi lingkungan permukiman di tepi sungai, yaitu kondisi kawasan padat penduduk, ketersediaan lahan terbatas, dan terbatasnya ruang publik (Rachmawati, Prakoso, Sadali, \& Yusuf, 2018). Berdasarkan identifikasi permukiman kumuh yang dilakukan pada tahun 2015, masing-masing kawasan permukiman kumuh di bantaran sungai memiliki kondisi yang berbeda. Terdapat pula karakteristik untuk permasalahan utama kawasan pada masing-masing klaster kawasan permukiman kumuh di Kota Yogyakarta (Bappeda Kota Yogyakarta, 2015). Pembagian klaster permukiman kumuh dan permasalahan utama secara umum disajikan pada Tabel 2.

Tabel 2. Permasalahan Utama Kawasan Permukiman Kumuh menurut Klaster Bantaran Sungai

\begin{tabular}{|c|c|}
\hline Klaster & Permasalahan Utama Kawasan \\
\hline Bantaran Sungai Winongo & $\begin{array}{l}\text { - Pengamanan bahaya kebakaran } \\
\text { - } \quad \text { Pembuangan air limbah } \\
\text { - } \text { Kepadatan bangunan } \\
\text { - } \quad \text { Saluran air hujan } \\
\text { - Jalan lingkungan }\end{array}$ \\
\hline Bantaran Sungai Code & $\begin{array}{l}\text { - Pembuangan air limbah } \\
\text { - Pengamanan bahaya kebakaran } \\
\text { - Jaluran air hujan } \\
\text { - Kepan lingkungan } \\
\text { - Ruang terbuka hijau }\end{array}$ \\
\hline Bantaran Sungai Gajah Wong & $\begin{array}{l}\text { - Saluran air hujan } \\
\text { - } \quad \text { Jalan lingkungan } \\
\text { - Penerangan jalan umum }\end{array}$ \\
\hline Bantaran Sungai Belik & $\begin{array}{l}\text { - Rumah tidak layak huni } \\
\text { - Pengelolaan persampahan } \\
\text { - Jalan lingkungan }\end{array}$ \\
\hline Selain Bantaran Sungai & $\begin{array}{l}\text { - Pengamanan bahaya kebakaran } \\
\text { - } \quad \text { Ruang terbuka hijau } \\
\text { - Pembuangan air limbah } \\
\text { - Penyediaan air bersih dan air minum }\end{array}$ \\
\hline
\end{tabular}

Sumber: Bappeda Kota Yogyakarta, 2015

Berdasarkan indentifikasi yang telah dilakukan, permasalahan yang hampir dimiliki permukiman kumuh yang berada di tepi sungai (bantaran sungai) adalah terkait salurah air hujan dan pembuangan air limbah. Kombinasi dari faktor manusia dan alam menghasilkan berbagai bahaya perkotaan dengan dampak serius pada orang miskin
(Ahmed, 2014). Permukiman kumuh tepi sungai di Kota Yogyakarta juga rentan terhadap bencana, terutama banjir dan longsor yang ditimbulkan/dipicu oleh erupsi Gunung Merapi (Mei et al., 2019). Hal ini tidak jauh berbeda dengan permukiman kumuh pesisir yang dipicu keterbatasan sanitasi masyarakat nelayan (Christiawan, Citra, \& Wahyuni, 2016). 


\section{Kesimpulan}

Kota Yogyakarta memiliki tiga sungai utama yang melintas di sisi barat (Sungai Winongo), sisi tengah (Sungai Code), dan sisi timur (Sungai Gadjah Wong). Distribusi spasial keberadaan kawasan permukian kumuh di Kota Yogyakarta berasosiasi dengan ketiga sungai utama yang membelah Kota Yogyakarta menjadi empat. Dengan demikian, kawasan permukiman kumuh yang ada di Kota Yogyakarta termasuk dalam kawasan permukiman kumuh di tepi air (KPKPS). Faktor utama yang mempengaruhi keberadaan permukiman kumuh di sekitar sungai di Kota Yogyakarta adalah ketidakmampuan masyarakat mengakses permukiman layak huni pada lahan peruntukan permukiman/perumahan. Sedangkan faktor utama munculnya kawasan permukiman kumuh di Kota Yogyakarta adalah kesadaran masyarakat untuk menjaga lingkungan bersih dan sehat, atau berkaitan dengan perilaku hidup bersih dan sehat (PHBS) para penghuni rumah. Selain itu, pengelompokan rumah tidak layak huni pada luas area tertentu juga berpotensi menjadi kawasan permukiman kumuh.

Kawasan permukiman kumuh di Kota Yogyakarta memiliki luas 264,90 Ha pada tahun 2015 atau 8,58 persen dari luas wilayah Kota Yogyakarta. Luasan kawasan permukiman kumuh paling besar berada di Kecamatan Umbulharjo, dengan luas 75,20 Ha (28,39 persen). Sedangkan luasan kawasan permukiman kumuh paling kecil berada di Kecamatan Danurejan, yaitu sebesar 7,12 Ha $(2,69$ persen). Permasalahan permukiman kumuh di sebuah kota memang banyak dijumpai di negara berkembang maupun negara maju. Upaya penanganan permukiman kumuh di Kota Yogyakarta perlu dilakukan melalui pendekatan sosial dan teknis. Pendekatan sosial dilakukan untuk memberikan edukasi dan pemahaman terhadap pentingnya hidup bersih dan sehat, sehingga bisa menjadi kebiasaan (budaya) atau berperilaku menjaga kebersihan lingkungan tempat tinggal/rumah. Pendekatan teknis dalam penanganan permukiman kumuh dilakukan untuk melakukan perbaikan rumah dan lingkungannya terkait dengan aspek-aspek kondisi fisik yang tidak bisa diakses oleh masyarakat penghuni permukiman kumuh, seperti perbaikan rumah, perbaikan sanitasi dan drainase (termasuk air bersih), perbaikan sarana prasarana mandi, cuci, kakus (MCK), serta fasilitias permukiman lainnya yang menunjang rumah layak huni.

\section{Daftar Pustaka}

Ahmed, I. (2014). Factors in Building Resilience in Urban Slums of Dhaka, Bangladesh. In 4th International Conference on Building Resilience, Building Resilience. (pp. 745-753). Salford Quays: Procedia Economics and Finance.

Bappeda Kota Yogyakarta. (2015). Laporan Pendataan Perumahan dan Permukiman Kumuh di Kota Yogyakarta Tahun 2015. Yogyakarta.

Beguy, D., Bocquier, P., \& Zulu, E. M. (2010). Circular Migration Patterns And Determinants in Nairobi Slum Settlements. Demographic Research, 23(4), 549-585.

Bytyqi, V. (2018). The Impacts of Settlement Extension on Soil Resources: A Case Study in Drenica River Basin ( Kosovo ). Media Komunikasi Geografi, 19(1), 101113.

Christiawan, P. I., \& Budiarta, I. G. (2017). Entitas Permukiman Kumuh Di Wilayah Pesisir. Jurnal IImu Sosial Dan Humaniora, 6(2), 178-187.

Christiawan, P. I., Citra, I. P. A., \& Wahyuni, M. A. (2016). Penataan permukiman kumuh masyarakat pesisir di desa sangsit. Jurnal Widya Laksana, 5(2), 52-59.

Fithra, H., Olivia, S., \& Siska, D. (2019). Analysis Reducing Slum Settlement by Road Improvement (A Case 
Study: Jawa Lama Village Village, Lhokseumawe, Aceh-Indonesia). Aceh International Journal of Science and Technology, 8(1), 20-28.

Mei, E. T., Putri, R. F., Sadali, M. I., Febrita, D., Yulandari, E. D., Anggriani, M., \& Niam, R. A. (2019). Sister School for Merapi Volcano Disaster Risk Reduction. In International Conference on Environmental Resources Management in Global Region (pp. 1-9). Yogyakarta: IOP Publishing.

Rachmawati, R., Prakoso, E., Sadali, M. I., \& Yusuf, M. G. (2018). Riparian Planning In Yogyakarta City. Earth and Environmental Science, 148, 112.

Ritohardoyo, S., \& Sadali, M. I. (2017). Kesesuaian Keberadaan Rumah Tidak Layah Huni (RTLH) Terhadap Tata Ruang Wilayah di Kota Yogyakarta. Tata Loka, 19(4), 291305.

Setiadi, A. (2014). Tipologi Dan Pola Penanganan Permukiman Kumuh Di Kota Bontang. Tata Loka, 16(4), 220233.

Sulestianson, E., \& Indrajati, P. N. (2016). Penanganan Permukiman Kumuh Dengan Pendekatan Karakteristik dan Faktor Penyebab Kekumuhan (Studi Kasus: Permukiman Kumuh di Kelurahan Tamansari dan Kelurahan Braga). Jurnal Perencanaan Wilayah Dan Kota, 3(2), 261-270.

Uddin, N. (2018). Assessing Urban Sustainability of Slum Settlements in Bangladesh: Evidence from Chittagong City. Journal of Urban Management, 7(1), 33-42. 